\section{Tutankhamun's Dentition: The Pharaoh and his Teeth}

\author{
Niels Christian Pausch¹, Franziska Naether², Karl Friedrich Krey ${ }^{3}$
}

Tutankhamun was a Pharaoh of the 18th Dynasty (New Kingdom) in ancient Egypt. Medical and radiological investigations of his skull revealed details about the jaw and teeth status of the mummy. Regarding the jaw relation, a maxillary prognathism, a mandibular retrognathism and micrognathism have been discussed previously. A cephalometric analysis was performed using a lateral skull X-ray and a review of the literature regarding King Tutankhamun's mummy. The results imply diagnosis of mandibular retrognathism. Furthermore, third molar retention and an incomplete, single cleft palate are present.
'Department of Oral and Maxillofacial Surgery, University Hospital of Leipzig, Leipzig, Germany 2Institute of Egyptology/Egyptian Museum Georg Steindorff, University of Leipzig, Leipzig, Germany ${ }^{3}$ Department of Orthodontics, University Hospital of Greifswald, Greifswald, Germany

Correspondence: Dr. Niels Christian Pausch, Liebigstraße 12, 04103 Leipzig, Germany. Tel: +49341-97-21160. e-mail: niels. pausch@medizin.uni-leipzig.de

Key Words: Tutankhamun's dentition, cephalometric analysis, mandibular retrognathism

\section{Introduction}

In 1922, the British Egyptologist Howard Carter found the undisturbed mummy of King Tutankhamun. The spectacular discovery enabled scientists of the following decades to analyze the Pharaoh's remains. The mummy underwent multiple autopsies. Until now, little was published about the jaw and dentition of the King. The first autopsy was performed by Carter and Derry in 1925 (1). Their investigation of the jaw and teeth revealed 3 partially erupted third molar teeth. This finding led to the first estimation of the king's age, which was presumed to be between 18 and 22 years old at the time of his death. Further investigations of the mummy were performed in 1968 and 1978 focusing the x-ray analysis of the skull. Discovered bone fragments in the skull cavity suggested that a traumatic event of the head might have killed Tutankhamun $(2,3)$. This theory was later refuted by Boyer et al. (4), who demonstrated that these bone fragments were a result of the rough autopsy made by Carter and Derry (1).

A computer tomography (CT) scanning performed in 2005 produced further digestions about the mummy and especially the head of the Pharaoh (5). The results of this investigation provided a detailed view regarding jaws, teeth and paranasal sinuses of the mummy. In the decades before the CT, physical features of Pharaoh Tutankhamun have produced much speculation. Some of these theories assumed the presence of a Marfan syndrome, WilsonTurner syndrome, Klinefelter syndrome, Antley-Bixler syndrome or sagittal craniosynostosis syndrome (6-9). The CT investigation of the mummy body in 2005 and again in 2010 excluded these suppositions, but perpetuated the theory of a maxillary prognathism or a mandibular retrognathism $(5,10)$. A mandibular micrognathism has also been discussed (11).

\section{Case Report}

In the evaluation of Tutankhamun's dentition and jaw alignment, contemporary face reconstructions and coeval artistic images can be of further use. However, the ancient portrayals are influenced by the style of the Amarna period, which represents a strange, androgynous esthetic (12). These and other artifacts like the famous golden mask of the Pharaoh (Fig. 1) displays a gracile lower face. This

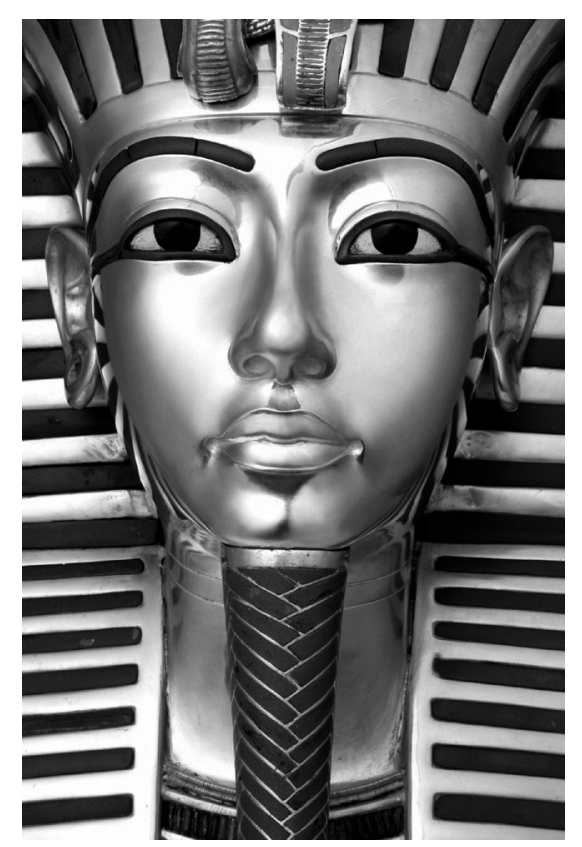

Figure 1. Detail of the golden mask of Pharaoh Tutankhamun (replica). The short dimension of the lower face is obvious. 
finding corresponds to the (unpublished) x-ray image, which was performed by Harrison in 1968 and published by Boyer et al. in 1991 (4) (Fig. 2). This lateral x-ray reveals a sagittal discrepancy of maxilla and mandible. The lower jaw appears small and retarded. Sagittal ante-inclination of the anterior mandibular teeth compensates the deficit between maxilla and mandible.

In this work was performed a facial soft tissue reconstruction according to the lateral X-ray of Figure 2 using the MorphMan 4.0 software (Stoik Imaging Ltd, Moscow, Russia) (Fig. 3). This soft tissue reconstruction reveals the typical appearance of Angle class II malocclusion. Additionally, a cephalometric analysis using the software OnyxCeph 3TM, (Image Instruments, Chemnitz, Germany) was carried out (Fig. 4) according to Segner and Hasund (13) and Thekkaniyl et al. (14). Table 1 displays the computed SNA, SNB and ANB angles. The results of the analyses indicate a mandibular retrognathism.

While conventionally X-ray analyses of the pharaoh's skull are of limited value for the assessment of the teeth conditions, the $\mathrm{CT}$ investigation provides more information about Tutankhamun's dentition. Hawass et al. reported about three partially erupted and malaligned third molar

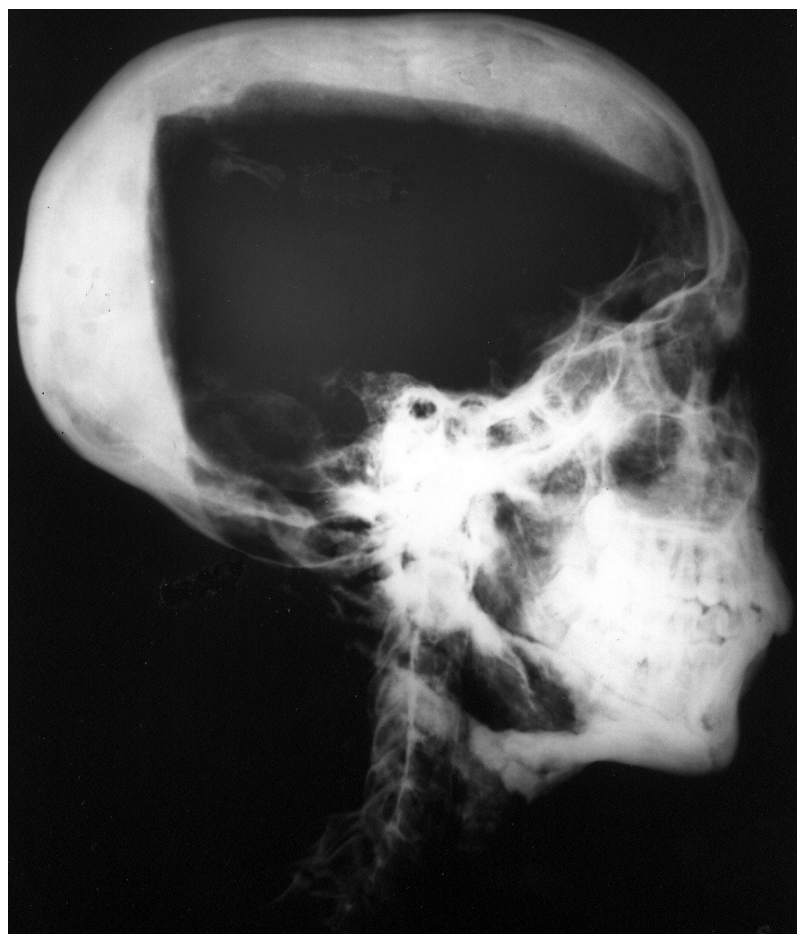

Figure 2. Lateral skull radiograph, performed by Harrison in 1968. also illustrates the presence of radio-attenuated material in the nasal and oral cavity. These masses are resin plugs result of the embalming process.

\section{Discussion}

Already in 1896, just three months after the discovery of X-rays, first images of mummies were performed (15). Since the seventies, CT imaging has been in use for noninvasive analysis of archaeological remains (16). Zweifel et al. published a systematic review of all studies that deal with scientific aspects of mummies and found 131 articles in Pubmed in the period between 1977 and 2005 (17). However, very few studies investigated dental details of mummies (18-22). As many as 27 articles indexed in Pubmed report directly or indirectly about Tutankhamun. So, very little information about his teeth and jaw relation have been published so far.

CT investigations of Tutankhamun's skull revealed an excellent condition of the king's dentition. Crowding of the frontal mandibular teeth as a sequel of the limited space in the dental arch may be noted (11). No caries, missing teeth, or parodontal diseases were found (5). In contrast to these findings, caries decay of the teeth of Egyptian aristocrats is a frequent observation, effect of a copious consumption of processed carbohydrates. Tutankhamun's dentition was also free of abrasions. This indicates a high grade of nourishment without soiling of grit or sand $(14,18)$.

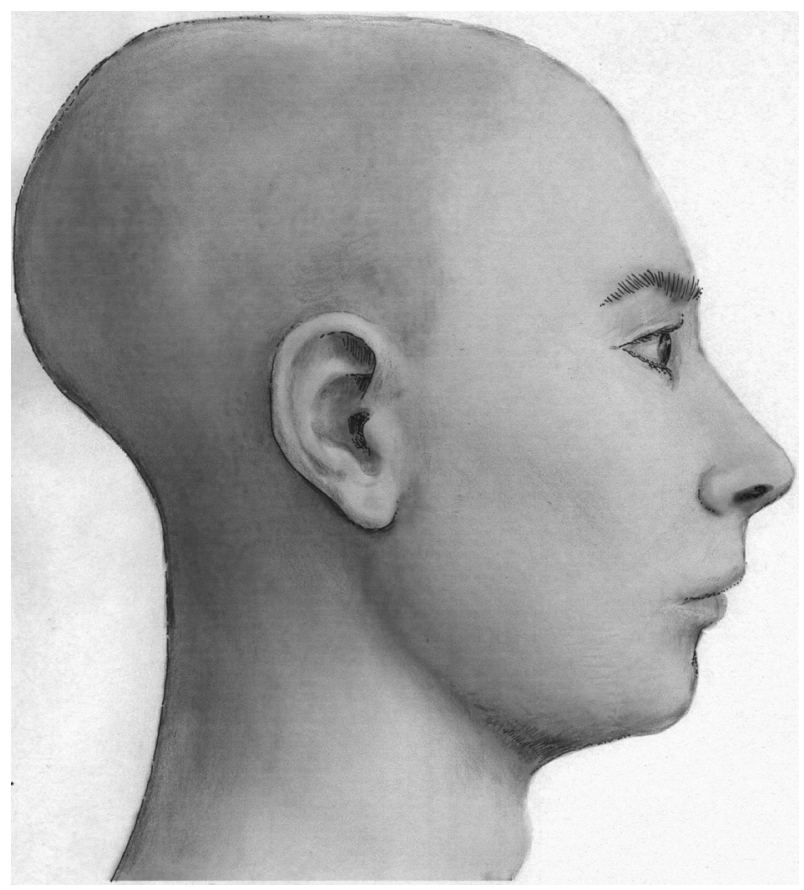

Figure 3. Lateral face reconstruction of pharaoh Tutankhamun. The shape of the nose is notional. 
Food-associated attrition of the teeth with pulpal exposure was observed in several cases of Egyptian mummies (21). It remains unclear whether or not dental treatment was

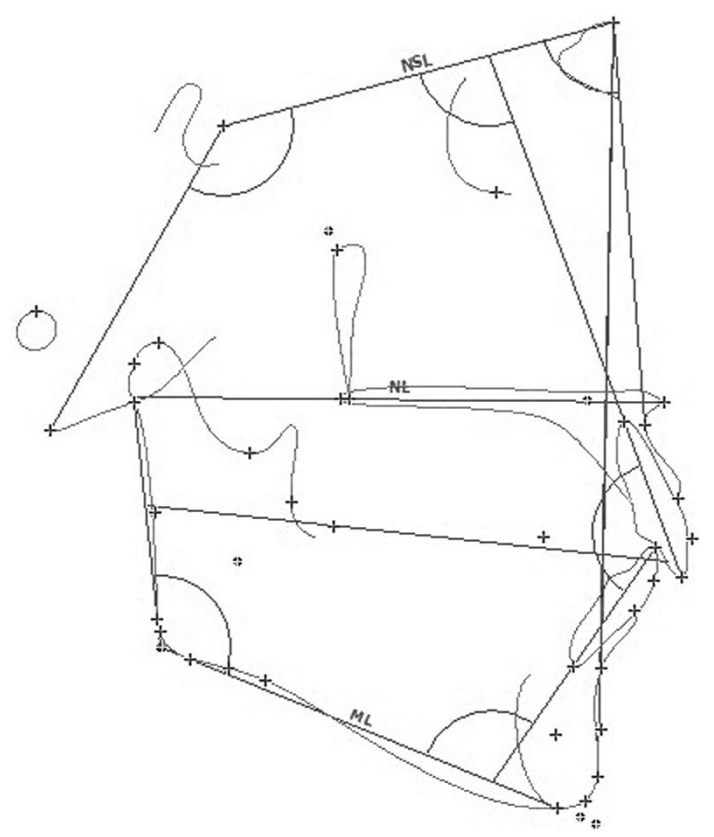

Figure 4. Cephalometric analysis according to Segner and Hasund, based upon Figure 2. NSL= Nasion-Sella-Line; $\mathrm{ML}=$ Mandibular line.

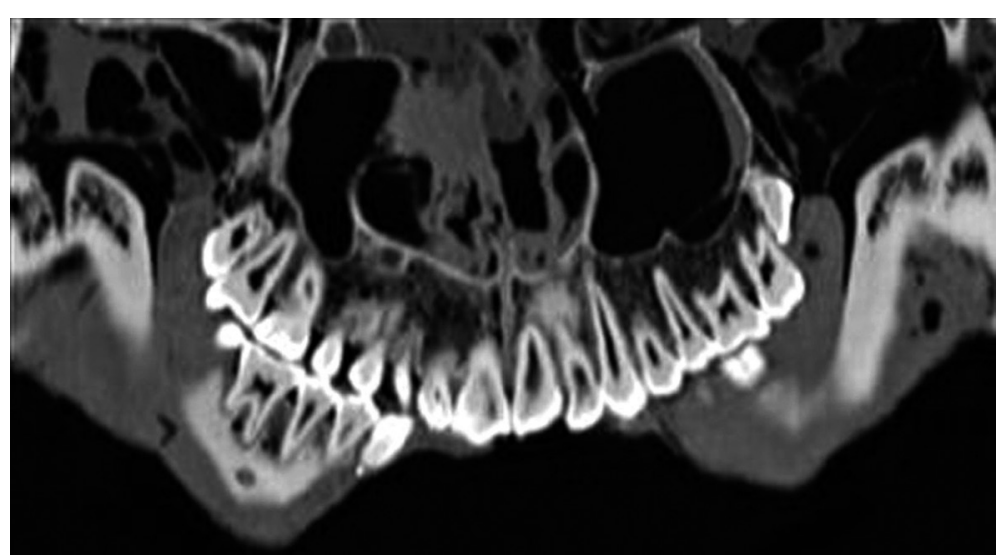

Figure 5. Orthopantomography based on a CT scan (tooth 18 is partially erupted and 28 is unerupted).

Table 1. Results of the cephalometric analysis

\begin{tabular}{lcccc}
\hline $\begin{array}{l}\text { Angle } \\
\text { (in degree) }\end{array}$ & Tutankhamun & $\begin{array}{c}\text { Averages for modern } \\
\text { Egyptian adult males* }\end{array}$ & $\begin{array}{c}\text { Averages for } \\
\text { Europeans** }^{* * *}\end{array}$ & $\begin{array}{c}\text { Averages for } \\
\text { male Pharaohs* }\end{array}$ \\
\hline SNA & 83.8 & 82.7 & $82.0+/-3$ & 83.0 \\
SNB & 77.8 & 80.0 & $80.0+/-3$ & 76.0 \\
ANB & 6.0 & 2.7 & $2.0+/-2$ & 7.0 \\
\hline
\end{tabular}

Complete data are not shown, but available upon request. *According to Thekkaniyil et al. (14) and Harris et al. (23). **According to Segner and Hasund (13). available in ancient Egypt. The presence of prosthetics and oral surgery in ancient Egypt is also discussed controversially (19). Two studies report about mummies with missing molars which have probably been extracted $(14,21)$.

Interesting findings in the current report case are the resin plugs in the oral cavity. They fill out the space between the cheek and the maxillary and mandibular lateral teeth. Saleem and Hawass (22) reported in a previous article about subcutaneous packing in royal Egyptian mummies, including King Tutankhamun, which was instilled through skin incisions. However, it remains unclear whether the cheek and intraoral resin masses in this case have been injected by separate approaches or might have entered this space by a transoral approach.

The findings of this report suggest that the jaw relation of King Tutankhamun was a Class II malocclusion. Previous publications considered the presence of a mild prognathism (this suggestion probably refers to the maxilla) (5) or a mandibular retrognathism (10). The result of the cephalometric analysis revealed a mandibular retrognathism (SNB $77.8^{\circ}$ ), no matter whether the reference values by Segner and Hasund or those of an average Egypt population are used. This finding suggests that the maxillofacial skull architecture of Tutankhamun fits in the series of retrognathic average values of Egypt's pharaohs $(14,23)$.

As a limitation of this study it must be considered the modest quality of the available X-ray from 1968. The image is not a standardized lateral cephalometric radiograph. Because of the embalming process and the bony decay, there are visible artifacts, which impede the identification of the cephalometric reference points. The skull was probably $\mathrm{X}$-rayed with a slight rotation around the sagittal axis, which may influence the result marginally. Because of manipulations under the embalming procedure and changes of the soft tissue, the position of the mandible might differ in comparison of the one from a live person. However, the jaw alignment of Tutankhamun's skull is well fixed by the occlusion. Cephalometric analyses of macerated skulls are not uncommon and can be performed with an error of less than $2^{\circ}(24,25)$. Therefore, it is possible to believe that the results of the cephalometry are reliable and the diagnosis "mandibular retrognathism" in the case of Pharaoh Tutankhamun can be confirmed. 


\section{Resumo}

Tutankhamun foi um faraó da $18^{a}$ dinastia (Novo Império) do antigo Egito. Estudos médicos e radiológicos de seu crânio revelaram detalhes sobre o estado dos dentes e mandibula da múmia. Já houve relatos sobre a relação mandibular, o prognatismo maxilar, retroganatismo e micrognatismo mandibular. Neste estudo foi feita análise cefalométrica com radiografia lateral e uma revisão da literatura a respeito da múmia do faraó Tutankhamun. Os resultados levam à conclusão de retrogantismo mandibular. Também estão presentes retenção de terceiro molar e fissura palatina singular incompleta.

\section{References}

1. Carter H, Mace AC. The tomb of Tutankhamun. In: Leek FF, Harris JR (Eds.): The Human Remains from the Tomb of Tutankhamun, Tutankhamun's Tomb Series V, Oxford, 1927.

2. Harrison RG. Post mortem on two pharaohs: was Tutankhamen's skull fractured? Buried History 1971;4:114-129.

3. Harrison $R G$, Abdalla $A B$. The remains of Tutankhamun. Antiquity 1972;46:8-14.

4. Boyer RS, Rodin EA, Grey TC, Connolly RC. The skull and cervical spine radiographs of Tutankhamen: a critical appraisal. Am J Neurorad 2003;24,1142-1147.

5. Hawass, Z, Shafik M, Rühli FJ, Selim A, ElSheikh I, Abdel Fatah S, et al.. Computed tomographic evaluation of Pharaoh Tutankhamun, ca. 1300 BC. Ann Serv Antiq Egypt 2009;81,159-174.

6. Walshe JM. Tutankhamun: Klinefelter's or Wilson's? Lancet 1,1973;7794:109-110.

7. Gray JE. Tutankhamun post mortem. Lancet 3,1973;7797:259.

8. Paulshock BZ. Tutankhamun and his brothers: familial gynecomastia in the Eighteenth Dynasty. JAMA 1980;244:160-164.

9. Braverman IM, Redford DB, Mackowiak PA. Akhenaten and the strange physiques of Egypt's 18th dynasty. Ann Intern Med 2009;150:556-560.

10. Hawass $Z$, Gad $Y Z$, Ismail $S$, Khairat $R$, Fathalla D, Hasan $N$, et al.. Ancestry and pathology in King Tutankhamun's family. JAMA 2010;303:638-647.

11. Hussein $\mathrm{K}$, Brix $A$, Matin $E_{1}$ Jonigk D. Tutankhamun: evidence-based paleopathology versus "curse of the pharaoh". Pathologe 2015;36:186192.

12. Jorgensen M. Egyptian art from the Amarna period. Exhibition held at the Ny Carlsberg Glyptotek 15th October 2005-30th April 2006. Kopenhagen Ny Carlsberg Glyptothek 2005.
13. Segner D, Hasund A. Individualisierte Kephalometrie. 3rd ed. Hamburg, Germany: Segner Verlag \& Vertrieb; 1998.

14. Thekkaniyil JK, Bishara SE, James MA. Dental and skeletal findings on an ancient Egyptian mummy. Am J Orthod Dentofacial Orthop 2000;117:10-14.

15. König W. Vierzehn Photographien mit Röntgen-Strahlen: aufgenommen im Physikalischen Verein zu Frankfurt a.M. J.A. Barth-Verlag Leipzig 1896.

16. Lewin PK, Harwood-Nash DCF. X-ray computed axial tomography of an Egyptian brain. IRCS Med Sci 1977;5:78

17. Zweifel L, Büni T, Rühli FJ. Evidence-based palaeopathology: metaanalysis of PubMed-listed scientific studies on ancient Egyptian mummies. Homo 2009;60:405-427.

18. Haase S, Pirsig W, Parsche. Surgical findings in an Egyptian mummy's skull. Dtsch Z Mund KieferGesichtschir 1991;15:156-160.

19. Nickol T, Germer R, Lieberenz $S$, Schmidt F, Wilke W. An examination of the dental state of an Egyptian mummy by means of computer tomography: a contribution to dentistry in Ancient Egypt. J Hist Dent 1995;43:105-112.

20. Motamed M, Alusi G, Campos J, East C. ENT aspects of the mummification of the head in ancient Egypt: an imaging study. Rev Laryngol Otol Rhinol (Bord) 1998;119:337-339.

21. Melcher AH, Holowka S, Pharoah M, Lewin PK. Non-invasive computed tomography and three-dimensional reconstruction of the dentition of a 2800-year-old Egyptian mummy exhibiting extensive dental disease. Am J Phys Anthropol 1997;103: 329-340.

22. Saleem SN, Hawass. Subcutaneous packing in royal Egyptian mummies dated from 18th to 20th dynasties. J Comput Assist Tomogr 2015;39:301-306

23. Harris JE, Kowalski C, Walker GF. Craniofacial variation in the royal mummies. In: Harris JE, Wente EF (ed.) An x-ray atlas of the royal mummies. Chicago: University of Chicago Press, 1980; pp. 346-363.

24. Argyropoulos E, Sassouni V, Xeniotou A. A comparative cephalometric investigation of Greek craniofacial pattern through 4,000 years. Angle Orthod 1989;59:195-204.

25. Tng TH, Chan TCK, Hägg U, Cooke MS. Validity of cephalometric landmarks. An experimental study on human skulls. Eur J Orthod 1994;16:110-120. 